\title{
Schattenriss (Silhouette)
}

\section{Catriona MacLeod}

To cite this article: MacLeod, Catriona. "Schattenriss (Silhouette)." Goethe-Lexicon of Philosophical Concepts 1 , no. 1 (2021): 74-82.

To link to this article: https://doi.org/10.5195/glpc.2021.20

Published by the University Library System, University of Pittsburgh.

\section{(c)}

Entries in this Lexicon are licensed under a Creative Commons Attribution 4.0 United States License.

Copyright $\odot$ the Author(s). 


\section{Schattenriss (Silhouette)}

The lexeme Schattenriss (silhouette) refers to an object that is suggestive of why materiality matters to Goethe's philosophical thought. It touches on several intellectual and aesthetic areas, including semiotics (natural versus arbitrary signs), art, physiognomy, anthropology, color theory, and epistemology. A popular reproductive artform of the late eighteenth century, the silhouette entered into Goethe's own collecting and artistic practices already in the 1770s. Collaboration with Johann Caspar Lavater (1741-1801) extended the significance of the silhouette profile into the scientific arena and built on Enlightenment visual agendas. The Schattenriss is also connected with eighteenth-century theories of mimesis and representation that concern related terms like Umriss (outline, contour) and also appear in Goethe's aesthetic writings. In his later work on color theory and the art-making activities of the Johanna Schopenhauer salon, however, Goethe focuses on the shadowy interior and the colorful shades of the shadow rather than the static line of the Umriss to take the silhouette into striking new scientific and aesthetic territory.

\section{Introduction}

The Grimms' Wörterbuch offers two main definitions of Schattenrisz. The first one, which Werther's creation of a silhouette of Lotte after three failed attempts at her portrait exemplifies, delineates it as "die abbildung eines körpers nach dem schatten [.. .] sodann allgemeiner von einem umrisz" (the representation of a body after its shadow [.. .] and more generally by a contour), while the second one describes it, more narrowly, as "das nach dem schatten gemachte profilbild des gesichtes, silhouette" (the profile of a face created after a shadow, silhouette). ${ }^{1}$ Turning to the German etymology of Schattenriss, a word adjacent to the term Umriss (the contour line that enjoys such abundance and popularity in neoclassical art and aesthetics), we should note that while Riss has referred to the line of a drawing or a drawing itself since the sixteenth century and is connected to the English "writ," it also carries the cutting-related meanings of Furche (groove), Kluft (fissure), and Spalt (crack).

Obviously a Schattenriss falls into the category of a singular thing or technique rather than an idea or a concept, albeit a thing that is part of the sensual world inhabited by Goethe and addressed across his oeuvre. If Bill Brown asked rhetorically in 2001 why we should not "let things alone $[. .$.$] in the balmy elsewhere beyond theory," 2$ this entry aims to open up an apparently banal object across a conceptual network of aesthetic, scientific, and indeed philosophical problems. It does so in the context of material culture approaches to Goethe such as the 2012 edited volume Weimarer Klassik: Kultur des Sinnlichen (Weimar Classicism: A Culture of the Sensible) ${ }^{3}$ and against a broader backdrop of thing theory (Bill Brown) and the heterogeneous new materialisms of Jane Bennett and Timothy Morton. As Goethe noted in Campagne in Frankreich (1822; Campagne in France):

Namhafte ältere Männer wurden, wo nicht persönlich, doch im Bilde verehrt; und es durfte auch wohl ein junger Mann sich nur einigermaßen bedeutend hervortun, so war alsbald der Wunsch nach persönlicher Bekanntschaft rege, in deren Ermangelung man sich mit seinem Porträt begnügte; wobei denn die, mit Sorgfalt und gutem Geschick, aufs genaueste gezogenen Schattenrisse willkommene Dienste leisteten. Jedermann war darin geübt, und kein Fremder zog vorüber, den man nicht Abends an die Wand geschrieben hätte; die Storchschnäbel durften nicht rasten. (FA 1.16:530) ${ }^{4}$

Notable men, advanced in life, were reverenced, if not personally, at least in their pictures; and a young man had only to distinguish himself in any way, to make his personal acquaintance sought after everywhere, and if this could not be accomplished, they contented themselves with 
his portrait; for which purpose the profiles drawn by the shade on the wall were found very useful, affording, when carefully and well done, an exact likeness. Every body was practiced in this, and no stranger passed through without having himself inscribed in the evening on the wall: the pantographs were not allowed to rest. ${ }^{5}$

With the pantograph in the background working in overdrive to capture and reproduce passing strangers in silhouette form, this article on the Schattenriss (silhouette) addresses a term that might not have immediately obvious philosophical connotations or relevance or even appear to constitute a Begriff. Admittedly, we almost seem to be on the level of a dating app when we read of Goethe being given by Lavater's close friend Dr. Johann Georg Zimmermann, among dozens of other silhouettes to study, one of Charlotte von Stein: from this image he created a character study with which he fell in love before meeting her in person. ${ }^{6}$ Certainly this attachment to the silhouette reflects eighteenth-century Sentimentalism and its culture of memory and feeling (as in Werther's clinging to an object that functions as an ersatz or relic of his beloved). Yet as a material object that had become a fashionable consumer article in the late eighteenth century-adorning luxury items such as porcelain and jewelry-it is also deeply connected with aesthetic/philosophical considerations that reach back into antique conceptions of art and representation and are fertile ground for Goethe's aesthetic and scientific thought, as well as that of his contemporaries. ${ }^{7}$ Challenging the notion that a turn to the material world represents a shift away from more theoretical concerns, Goethe's sensual orientation to the "thingly" world and his thinking with and through it—his "gegenständliches Denken" (object-oriented thinking) ${ }^{8}$ - suggest that we consider as well how the material object may also be in dialog with the philosophical in his thought. ${ }^{9}$ Furthermore, it is equally important to consider how "weakly theoretical" artifacts in fact call attention to knowledge production in specialized fields. ${ }^{10}$

Let us remember that Goethe's entrée into the court culture of Weimar had been marked by his own theatrical self-monumentalization of the miniature and, at that time, the aristocratic art of silhouettes. The occasion was a courtly festivity in 1781 at Tiefurt, Duchess Anna Amalia's summer residence. At the end of the performance of "The Birth of Minerva" in ombres chinoises, a winged genius magically appeared in the clouds, bearing Goethe's name. ${ }^{11}$ Goethe was both an avid creator and collector of

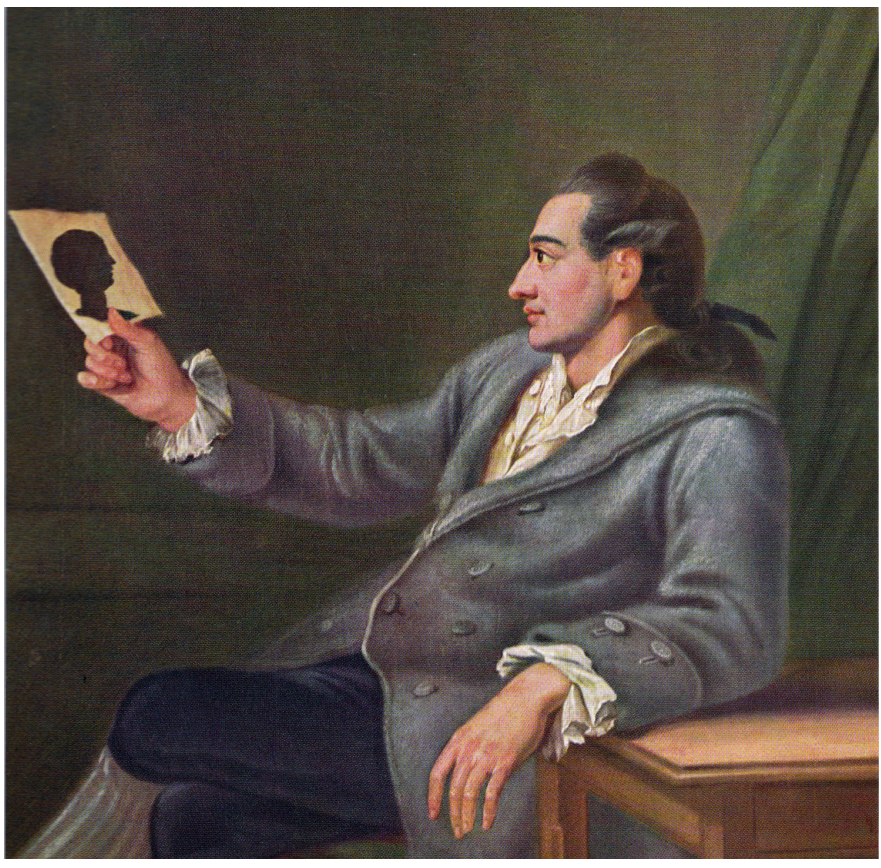

Fig. 1. Georg Melchior Kraus, Johann Wolfgang von Goethe, eine Silhouette betrachtend (Goethe with the Silhouette), 1775, copy from 1778 for Goethe's parents. Oil on canvas. 49.8 x $42.4 \mathrm{~cm}$. Frankfurt am Main, Goethe Museum.

silhouettes. The Goethe-Handbuch article on his art collection relegates this subcategory to the status of a marginal, not-quite Kunstsammlung (art collection). But it also notes that by the time of his death Goethe had amassed as many as 1226 Schattenrisse, which constituted an archive of friends and personalities. ${ }^{12}$ And he created his own silhouette portraits of Anna Amalia, Wieland, and Fritz von Stein, among others. ${ }^{13}$ As artist Philipp Otto Runge, the creator of a huge corpus of botanical papercuts, would remark on Goethe's "child-like" appetite for cutouts and silhouettes, "es ist doch ein recht großes Kind darin" (there is certainly a grown child in there). ${ }^{14}$

In what follows, we shall see that the Schattenriss has paradoxically been defined in terms of its evidentiary truthfulness (Lavater), on the one hand, and its absence of truth content, or what Goethe described as its shadowy and elusive "half-reality," on the other. This contradiction, I argue, which is actually a constitutive ambiguity, opens up the conceptual potential of a captivating social artform that is based in epistemological negation and opacity. In other words, there is more to the Schattenbild of Lotte hanging in the room where Werther commits suicide - and which he covers in feverish kisses before taking his life (FA 1.8:261-62) - than a high-end, dilettantish object. That object takes diverse forms and goes by several 


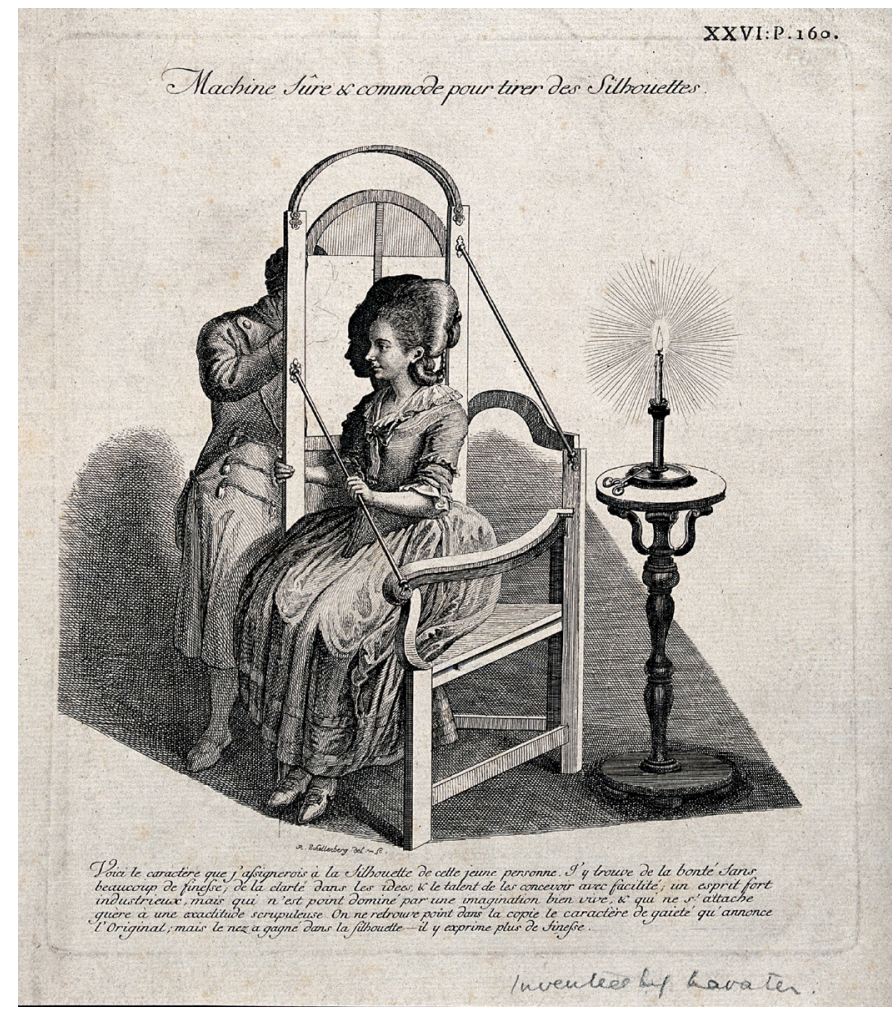

Fig. 2. J. R. Schellenberg, A Man Drawing the Silhouette of a Seated Woman on Translucent Paper Suspended in a Frame and Lit by a Candle, 1783. Etching. 24.1 x $19.6 \mathrm{~cm}$. Wellcome Images.

appellations around 1800, which also touch importantly on the purposes of this discussion and support the suggestion that the Schattenriss is not only a thing, but also a concept. These forms are (1) the silhouette and (2) the Scherenschnitt (papercut).

\section{Silhouette and Papercut}

Itself a precursor medium to the dominant new reproductive technology of the nineteenth century, photography, the silhouette was a machine-aided reproduction created by projecting the subject's image on a screen and then tracing and cutting its outline. By the 1780 s, silhouette machines had been invented that required little training, and they came to include technical devices such as the pantograph or physionotrace, which permitted reproduction and miniaturization. Johann Caspar Lavater devised a silhouette machine that immobilized a female subject behind a screen and captured it in a manner visually reminiscent of the confessional. ${ }^{15}$ Lavater's machine also had shades of that other bladed innovation of the age: the guillotine, with its output of disembodied heads.${ }^{16}$ Something of the torture device adheres in Goethe's description, above, of a stream of visiting strangers fixed to the wall ("an die Wand geschrieben") by the Storchschnabel, or pantograph. And Jean Paul's excruciating description in the novel Siebenkäs (1796-97) of a resistant woman's torso and head being pressed flat onto a silhouette board, as if by a pocketknife, is even more extreme. ${ }^{17}$ Itinerant silhouette artists plied their trade in market settings. Lavater devised a wildly successful marketing strategy for his Physiognomische Fragmente (1775-78; Physiognomic Fragments), inviting the public to submit silhouettes. ${ }^{18}$ Doing something à la silhouette in the late eighteenth century meant doing it cheaply and crudely. Indeed, named as it was after the French ancien régime finance minister Étienne de Silhouette, a promoter of unpopular austerity measures, the very term connoted thrift. ${ }^{19}$ This kind of production and technique was also familiar to Goethe, who was himself an avid silhouettist in his early adulthood, as attested by his art teacher Georg Melchior Kraus (1737-1806). ${ }^{20}$

In contrast to the silhouette portrait, the Scherenschnitt, a salon product executed with the fine scissors used for needlework and dominantly a female craft, exemplified and refined dexterous skills. Its name doubly focuses our attention on the cutting tool, rather than the shadow that dominates the word denoting the Schattenriss as a technique. Here the Weimar setting of Johanna Schopenhauer's bourgeois salon is significant as both a sociable and aesthetic space where Philipp Otto Runge's

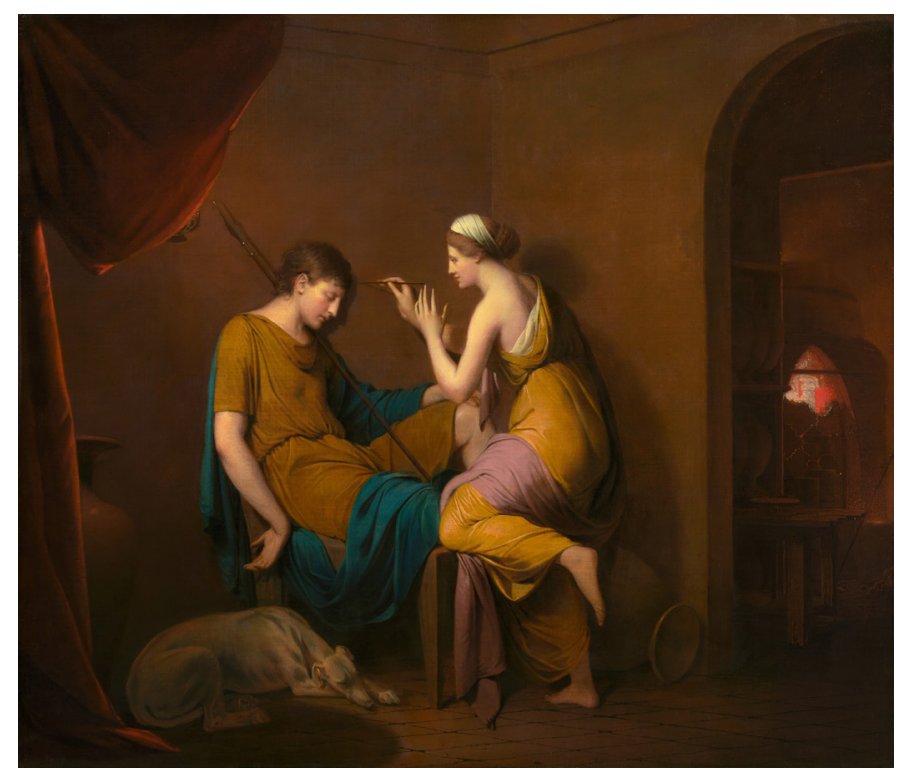

Fig. 3. Joseph Wright of Derby, The Corinthian Maid, 1782-84. Oil on canvas. $106.3 \times 130.8 \mathrm{~cm}$. National Gallery of Art, Paul Mellon Collection. 
botanical papercuts - sometimes considered plant physiognomies - found a vibrant reception. Johanna's daughter Adele, in fact-who was a thwarted author and sculptor-was celebrated for her virtuoso works in cut paper and would characterize herself as a "Halbschatten" (half shadow). ${ }^{21}$

\section{Ancient and Neoclassical Antecedents}

The shadow, according to myth, was the first painting and, not coincidentally, can also be connected with the birth of philosophy, which Plato's allegory of the cave also features as a projection. For Stoichita, moreover, whose influential book on shadow connects these twin origin stories, Plato's allegory is a sadistic tale of entrapment in murky shadows (Stoichita, Short History of the Shadow, 21-22) so that, from the earliest times the shadow has been integral to theories of representation and knowledge. According to Pliny the Elder, who draws on an older Greek myth, the origin of painting can be associated with an (unnamed) female artist, the potter Butades's daughter (also known as the Corinthian maid), who projects and then outlines her departing lover's profile on a wall by the light of a lantern (thereby also providing the inverse of Lavater's passive female subject and male technician):

Enough and more than enough has been said about painting. It may be suitable to append to these remarks something about the plastic art. It was through the service of that same earth that modeling portraits from clay was first invented by Butades, a potter from Sycion, at Corinth. He did this owing to his daughter, who was in love with a young man; and she, when he was going abroad, drew in outline on the wall the shadow of his face thrown by the lamp. Her father pressed clay on this and made a relief, which he hardened by exposure to fire with the rest of his pottery; and it is said that this likeness was preserved in the shrine of the nymphs. ${ }^{22}$

In Pliny's account, we find the creation of a contour drawing (Umriss), followed by a process of modeling in clay (which would be the most interesting part of the story for Winckelmann) without the subtractive cutting action of the eighteenth-century Schattenriss. What is notable about the many renderings of the Plinian tale in neoclassical and romantic art is that several relocate the setting of the projection screen away from the dark interior space and into bright sunlight-as in Karl Friedrich Schinkel's gouache Die Erfindung der Zeichenkunst (1830; The In-

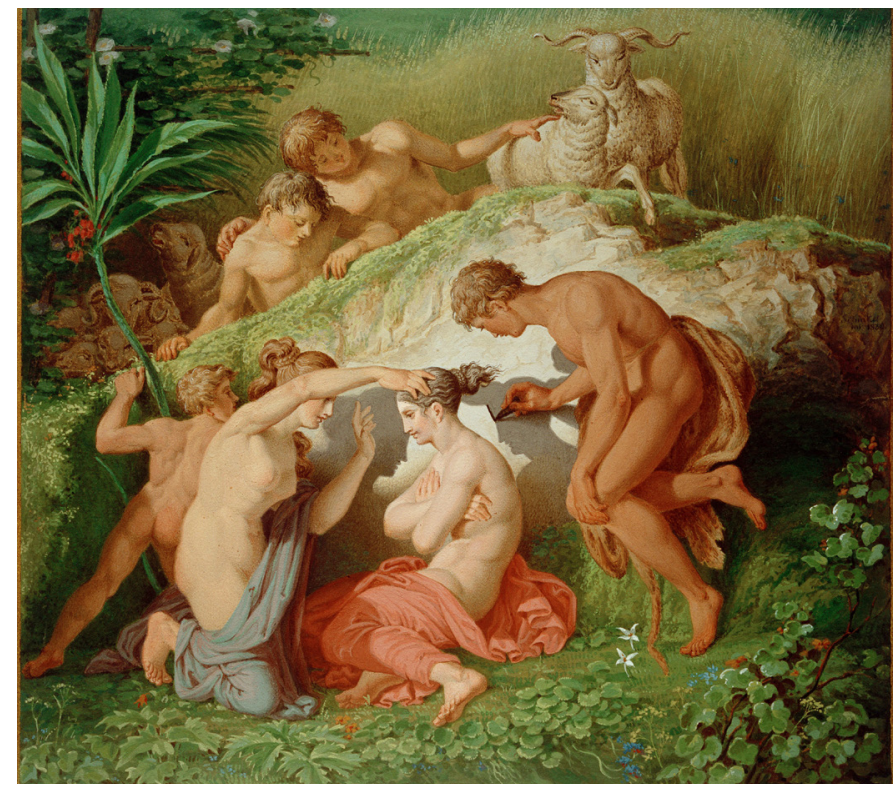

Fig. 4. Karl Friedrich Schinkel, Die Erfindung der Zeichenkunst (The Invention of Drawing), 1830. Gouache. $26 \times 29 \mathrm{~cm}$. Wuppertal, Von der Heydt-Museum. akg-images.

vention of Drawing), which also insists on the bold dark line of the contour mark drawn around and containing the shadow.

\section{Goethe's Ambivalences}

Stoichita's book on shadow reads German critic Joachim von Sandrart's influential recounting of the Plinian fable in 1675 as follows. Sandrart, he argues, wanted to show that the Corinthian maid's was a "primitive art" and viewed art itself as a shadow. European art, by contrast aimed "to endow the shadow-within the representation - with meaning" (Stoichita, Short History of the Shadow, 127). Stoichita leaves open the question of the status of this shadowy meaning. In Goethe's "Der Sammler und die Seinigen" (1799; The Collector and his Circle), the Schattenriss, as a manifestation of the worst excesses of portraiture, is assigned to imitation (Nachahmung) (FA 1.18:725-26), the first and most inferior category in the scheme of aesthetic production. ${ }^{23}$ As a kind of counterpoint to the grotesque, mimetically faithful wax statue that Goethe's collector commissions shortly before his death and that sits behind a curtain, imitations such as these uncanny silhouettes are not "behaglich" (FA 1.18:726; comfortable) and must be tucked away in portfolios. While we know that works on paper are susceptible to light damage, this is not only a practical matter of paper conservation. 
Despite their claims to mimetic fidelity, the Schattenrisse can only constitute shady, half-real representations of reality: "Die Neigung zu Schattenrissen hat etwas das sich dieser Liebhaberei nähert. Eine solche Sammlung ist interessant genug, wenn man sie in einem Portefeuille besitzt. Nur müssen die Wände nicht mit diesen traurigen, halben Wirklichkeitserscheinungen verziert werden" (FA 1.18:726; The fondness for silhouettes has something of this amateurism. Such a collection is interesting enough, when it is contained in a portfolio. But the walls should not be decorated with these sad, half-real representations of reality).

It may seem paradoxical, then, that Goethe had a collaborative relationship with Lavater as an editor and contributing author to the physiognomy project, which ignited the so-called Physiognomiestreit (physiognomy controversy) and would be intensively critiqued by thinkers such as scientists Georg Christoph Lichtenberg (1742-1799) and the satirical writer Johann Karl August Musäus (1735-1787). ${ }^{24}$ Goethe's friendship with Lavater, however, had chilled by the early 1780s. In addition to an article on mammalian skulls, moreover, Goethe has been identified as the "friend" in the dialog "Wie viel man aus den Schattenrissen sehen kann" (How much can one see in silhouettes?), which answers the uncertain question of how much, or indeed how little, can be confidently inferred of a human character from a silhouette with the enigmatic "'Alles Ja! - oder alles_Nein!'” (All things, yes! - or all-No!). ${ }^{25}$

Given Goethe's famously critical, if initially collaborative, relationship with Lavater ${ }^{26}$ it is striking that Lavater also notes the epistemological challenge presented by the Schattenriss in the Physiognomik that features Goethe in silhouette, without any identification by name, as evidence for the Genie. ${ }^{27}$ For Lavater, the profile of the shadow is the essential image and, thus, the locus of hermeneutic attention and activity. Nevertheless, he also holds that Schattenrisse are possessed of a peculiarly negative and vapid perfection- "das schwächste, das leereste, aber zugleich [...] das wahreste und getreueste" (the weakest, the emptiest, but at the same time [...] the most true and faithful) - and that they are weak and empty as a result of their technical reproducibility: "Was kann weniger Bild eines ganz lebendigen Menschen seyn, als ein Schattenriß? Und wie viel sagt er? wenig Gold; aber das reinste!" (Lavater, Physiognomische Fragmente, 2:90; What can be less the image of a living human being than a silhouette? And how much can it say? Little gold, but the purest. ${ }^{28}$ The dark shadow contained within the scientifically evidentiary profile could be advantageous if ignored. Were the viewer to become emotionally absorbed into that cryptic space, however - a black hole devoid of information - the silhouette would be problematic. In the case of a profile of Jesus, in fact, Lavater rejected the dark interior altogether and presented a series of outlines or Umrisse alone, which Stoichita aptly calls "shadows without shadows" (Stoichita, Short History of the Shadow, 167). ${ }^{29}$

\section{Conclusion}

Late in life Goethe would provide a helpful tool to assess the status of the black hole in his mature thinking when he commented on the arts and crafts in Johanna Schopenhauer's salon with a poem. He had known Johanna's daughter Adele (1797-1849) since the "enfant cheri" (dear child) - as Karl Immermann called her-was nine years old. Goethe delighted in playing with Adele and her dolls and wrote several verses to accompany her Scherenschnitte..$^{30}$ And while his responses to her work may often appear light-hearted, they also express some complex, if gendered, views about the form. Thus, in 1829, when he attached a poem to Schopenhauer's gift of a cutout scene to the Berlin painter Johann Gottlob Samuel Rösel (1768-1843) - a drawing teacher at the Berlin Kunstakademie - Goethe proposed it would be for Rösel, the male artist "to reshape" (umzubilden) the work by providing a rational outline (Umriss), light, and shade for "Adelens Klecksen" (FA 1.2:829; Adele's blots), to which he does not even accord the name Schattenriss. With its ironic term Klecks, however, Goethe's literary intervention places Schopenhauer's works alongside contemporary works such as the accidental, irrational inkblots of Justinus Kerner that constitute, as Juliane Vogel argues, unconscious "Störfälle auf der Szene des Schreibens und Zeichnens" (accidents on scenes of writing and drawing) and so anticipate experimental avant-garde collage practices of the early twentieth century. ${ }^{31}$ Goethe's poem also turns the reader's attention to the shapeless opaque center of the Schattenriss rather than to the contour line or Umriss, which appears to have vanished mysteriously from Schopenhauer's work or to have been transgressed and obliterated. This move places Goethe at odds with 
neoclassical approaches to the Umriss, which tended to emphasize the precise line and static shadow, a point on which Schiller would insist in his poem "Die Künstler" (1789; The Artists) when citing the Plinian tale: "Schuft ihr im Sand-im Thon den holden Schatten nach, / Im Umriß ward sein Dasein aufgefangen" (You recreated the lovely shadow in sand, in clay, / Whose essence was captured in the contour line)..$^{32}$ According to Goethe, however, Rösel is now charged with converting Schopenhauer's dark, formless work by means of his ornamental line into a contoured finished product, one that begins black, but ends in a less sinister manner: "freundlich" (friendly). Tellingly, Goethe's problem with Schopenhauer's papercuts in black paper is that their very blackness excludes the variability of light in "Schatten" (shadow, shade) - a returning concern in the Farbenlehre (1810; Theory of Colors), particularly in the section devoted to "Farbige Schatten" ("Colored Shadows"). Repeated empirical observations with "Finsternisstrahlen" (eclipse rays) yield the conclusion that shadows are not devoid of color, but rather, for the most part, colored and constantly shifting colors. Indeed, color itself is a shad-

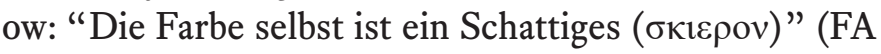
1.23:52; color itself is a shadow). To return to Goethe's playful objection to Schopenhauer, Rösel is instructed to imbue blackness with shades, thereaby creating a typically Goethean Schattenriss:
Schwarz und ohne Licht und Schatten

Kommen, Röseln aufzuwarten,

Grazien und Amorinen;

Doch er wird sie schon bedienen.

Weiß der Künstler ja zum Garten

Die verfluchtesten Ruinen

Umzubilden, Wald und Matten

Uns mit Linien vorzuhexen;

Wird er auch Adelens Klecksen,

Zartumrißnen, Licht und Schatten,

Solchen holden Finsternissen,

Freundlich zu verleihen wissen. (FA 1.2:828)

Black, without light or shade, Graces and Cupids arrive to lie in wait for Rösel; But he will soon attend to them. For the artist knows how to refashion the most wretched ruins into a garden and to conjure up forest and fog with lines. Thus, he will be able amiably to bestow delicately outlined light and shade to these dear dark spots, Adele's blots.

I would like to acknowledge the helpful and illuminating response provided by Frauke Berndt to my original presentation on this topic. I am also grateful for the suggestions of two anonymous reviewers.

Catriona MacLeod University of Chicago 


\section{Notes}

${ }^{1}$ Deutsches Wörterbuch von Jacob Grimm und Wilhelm Grimm, http://woerterbuchnetz.de/cgi-bin/WBNetz/wbgui_py?sigle=DWB\&mode=Vernetzung\&lemid=GS05148\#XGS05148, accessed 20 June, 2020.

2 Bill Brown, “Thing Theory," Critical Inquiry 28, no. 1 (2001): 1.

${ }^{3}$ See Weimarer Klassik. Kultur des Sinnlichen, eds. Sebastian Böhmer, Christiane Holm, Veronika Spinner, and Thorsten Valk (Berlin: Deutscher Kunstverlag, 2012).

${ }^{4}$ Works by Goethe are cited by section, volume, and page numbers according to the Frankfurt edition, abbreviated FA: Johann Wolfgang von Goethe, Sämtliche Werke, Briefe, Tagebücher und Gespräche, eds. Hendrik Birus, Dieter Borchmeyer, Karl Eibl, et. al., 40 vols. (Frankfurt a.M.: Deutscher Klassiker Verlag, 1987-2013). All translations, unless otherwise noted, are by the author.

${ }^{5}$ Goethe, Campaign in France in the Year 1792, trans. Robert Farie (London: Chapman and Hall, 1849), 231-32.

${ }^{6}$ Nicholas Boyle, Goethe: The Poet and the Age: The Poetry of Desire (1749-90) (Cambridge: Cambridge UP, 1991), 1:208. On the role of the silhouette in Weimar culture as both fashionable exchange object and subject of intellectual discussion, see Timotheus Kroeber, Die Goethezeit in Silhouetten (Weimar: Gustav Kiepenheuer, 1911). Hereafter cited in the text body as Kroeber, Die Goethezeit in Silhouetten.

${ }^{7}$ The associated words Umriss (outline, sketch) and Kontur (contour) are linked by Goethe with an epistemological tool, the Aperçu, as recorded in his diary by Friedrich Wilhelm Riemer (1774-1845) on May 2, 1819: "Es ist das Höchste, wozu es der Mensch bringt [. . .]. Es ist nur der Kontur, der Umriß von einer Sache" (FA 1.35: 269; it is the highest human achievement [. . .]. It is only the contour, the outline of a thing).

${ }^{8}$ See the essay "Bedeutende Fördernis durch ein einziges geistreiches Wort" (FA 1.24:596-99; Significant Progress through a Single Ingenious Word), as well as "Einwirkung der neueren Philosophie," where Goethe recalls treating the "Meinungen der Philosophen eben als wären es Gegenstände" (FA 1.24:442; opinions [beliefs, doxa, concepts] of philosophers as though they were objects).

9 The phrase was coined by Leipzig doctor Johann Heinroth, and accepted as apt by Goethe; see Eva Geulen, "Morphologie und gegenständliches Denken," Goethe Yearbook 26 (2019): 3-15.

${ }^{10}$ I have borrowed the term "weak theory" from Melanie Micir and Aarthi Vadde's article on the low-prestige scrapbooking activities of Virginia Woolf, "Obliterature: Toward an Amateur Criticism," Modernism/modernity 25, no. 3 (2018): 517-49.

${ }^{11}$ Karl Wilhelm Heinrich von Lyncker, Am Weimarischen Hofe unter Amalien und Karl August, ed. Marie Scheller (Berlin: E. S. Mittler, 1912), 118-19.

${ }^{12}$ Goethe-Handbuch Supplemente: Band 3: Kunst, eds. Gabriele Busch-Salmen, Manfred Wenzel, Andreas Beyer, and Ernst Osterkamp (Stuttgart: Verlag J. B. Metzler, 2008), 65-66.

${ }^{13}$ See Timotheus Kroeber, Die Goethezeit in Silhouetten, (Weimar: Gustav Kiepenheuer, 1911), 14.
${ }^{14}$ Letter to Daniel Runge, July 8, 1806, in Philipp Otto Runge: Briefe und Schriften, ed. Peter Bethausen (Munich: C. H. Beck, 1982), 187.

${ }^{15}$ Victor I. Stoichita, Short History of the Shadow (London: Reaktion, 1997), 164. Hereafter cited in the text body as Stoichita, Short History of the Shadow.

${ }^{16}$ William Chapman Sharpe, Grasping Shadows: The Dark Side of Literature, Painting, Photography, and Film, (New York: Oxford University Press, 2017), 117.

${ }^{17}$ Jean Paul, Blumen-, Frucht- und Dornenstücke oder Ehestand, Tod und Hochzeit des Armenadvokaten F. St. Siebenkäs, in Sämtliche Werke, ed. Norbert Miller, 10 vols. (Darmstadt: Wissenschaftliche Buchgesellschaft, 2000), 1.2:7-566, here: 131-32.

${ }^{18}$ Richard T. Gray, About Face: German Physiognomic Thought from Lavater to Auschwitz (Detroit: Wayne State University Press, 2004), xxxiii.

${ }^{19}$ Emma Rutherford, Silhouette: The Art of the Shadow (New York: Rizzoli, 2009); Ernst Biesalski, Scherenschnitt und Schattenrisse: Kleine Geschichte der Silhouettenkunst (Munich: Callwey, 1964).

${ }^{20} \mathrm{~W}$. D. Robson-Scott, The Younger Goethe and the Visual Arts (Cambridge: Cambridge University Press, 1981), 69.

${ }^{21}$ Letter to Goethe, August 28, 1824, in Geiger, "Dreizehn Briefe Goethes an Adele Schopenhauer," Goethe-Jahrbuch 19 (1898): 59. On the Schopenhauer salon, see Astrid Köhler, Salonkultur im klassischen Weimar: Geselligkeit als Lebensform und literarisches Konzept, (Stuttgart: Metzler, 1996). On the relationship between Adele Schopenhauer and Goethe, see MacLeod, "Cutting up the Salon: Adele Schopenhauer's 'Zwergenhochzeit' and Goethe's 'Hochzeitlied,'" Deutsche Vierteljahrsschrift für Literaturwissenschaft und Geistesgeschichte 89, no. 1 (2015): 70-87.

${ }^{22}$ Pliny the Elder, Natural History, ed. and trans. John Bostock and H. T. Riley (London: Taylor and Francis, 1855), Book 35, Chapter 43. http://www.perseus.tufts.edu/hopper/text?doc=Perseus:text:1999.02.0137:book=35: chapter $=43$ \&highlight $=$ butades .

${ }^{23}$ The arch-dilettante Werther attempts several portraits of Lotte before finally resorting to the silhouette, thus placing it, in that novel, several rungs below the portrait.

${ }^{24}$ On Musäus, see John P. Heins, “'Es ist ja kein Geschriebenes: The Parody of Lavater's Physiognomics in Musäus's Physiognomische Reisen," Lessing Yearbook 29 (1997): 107-30.

${ }^{25}$ Johann Caspar Lavater, Physiognomische Fragmente, 4 vols. (Leipzig and Winterthur: Bey Weidmanns Erben, und Heinrich Steiner und Compagnie, 1775-78), 2:94 ("Zwölftes Fragment"); Waltraud Hagen, Die Drucke von Goethes Werken, (Berlin: Akademie Verlag, 1971), 262.

${ }^{26}$ Goethe reminds us teasingly in Dichtung und Wahrheit (1833; Poetry and Truth) that a certain portrait painter from Frankfurt had sought to dupe Lavater by substituting a silhouette of the theologian Karl Friedrich Bahrdt (1741-1792) for the one he had requested of Goethe himself (WA 1.28:257-58).

27 "Die nachstehende Silhouette ist nicht vollkommen, aber dennoch bis auf den etwas verschnittenen Mund, der getreue Umriß von 
einem der größten und reichsten Genies, die ich in meinem Leben gesehen"; Lavater, Physiognomische Fragmente, 1:223 (The silhouette below is not perfect, and yet with the exception of the somewhat badly cut mouth it is the faithful outline of one of the greatest geniuses I have ever seen). Hereafter cited in the text body as Lavater, Physiognomicshe Fragmente.

${ }^{28}$ On Lavater and image reproduction, see John B. Lyon, “'The Science of Sciences: Replication and Reproduction in Lavater's Physiognomics," Eighteenth-Century Studies 40. 2 (2007): 257-77.

${ }^{29}$ Lavater, Essai sur la physiognomie, destiné à faire connoître l'homme et à le faire aimer, 4 vols. (La Haye: Imprimé chez Jaques Van Karnebeek, 1781-1803), 2:189 (plate XXXIV, facing page).

${ }^{30}$ Quoted in H. H. Houben, Kleine Blumen, kleine Blätter, 110.

${ }^{31}$ Juliane Vogel, "Schnitt und Linie. Etappen einer Liaison," in Öffnungen: Zur Theorie und Geschichte der Zeichnung, eds. Friedrich Teja Bach and Wolfram Pichler (Munich: Wilhelm Fink, 2009), 145.

${ }^{32}$ Robert Rosenblum, "The Origin of Painting: A Problem in the Iconography of Romantic Classicism," The Art Bulletin 39, no. 4 (1957): 285; Friedrich Schiller, "Die Künstler," in Sämtliche Werke, eds. Gerhard Fricke and Herbert G. Göpfert, 5 vols. (Munich: Carl Hanser, 1962), 1:173-87, here 176.

\section{Related Entries in the GLPC}

Ding (thing) Gegenstand (object) Materie (material) Riss (cut, tear) Umriss (outline, sketch)

\section{Works Cited and Further Reading}

Biesalski, Ernst. Scherenschnitt und Schattenrisse: Kleine Geschichte der Silhouettenkunst. Munich: Callwey, 1964.

Boyle, Nicholas. Goethe: The Poet and the Age: The Poetry of Desire (1749-90). Cambridge: Cambridge UP, 1991.

Brown, Bill. "Thing Theory." Critical Inquiry 28, no. 1 (2001): 1-22.

Deutsches Wörterbuch von Jacob Grimm und Wilhelm Grimm. Berlin-Brandenburgische Akademie der Wissenschaften and Akademie der Wissenschaften zu Göttingen. 33 vols. Leipzig and Munich: S. Hirzel and Deutscher Taschenbuch Verlag, 1854-1972. http://woerterbuchnetz.de/cgibin/WBNetz/wbgui_py?sigle=DWB\&mode $=$ Vernetzung\&lemid=GS05148\#XGS05148. Accessed 20 June, 2020.

Geiger, Ludwig. "Dreizehn Briefe Goethes an Adele Schopenhauer. Nebst Antworten der Adele und ei- nem Billet Börnes and Goethe." Goethe Jahrbuch 19 (1898): 53-119.

Geulen, Eva. "Morphologie und gegenständliches Denken." Goethe Yearbook 26 (2019): 3-15.

Goethe, Johann Wolfgang von. Campaign in France in the Year 1792. Translated by Robert Farie. London: Chapman and Hall, 1849.

-. Goethes Werke. Im Auftrag der Großherzogin Sophie von Sachsen. 143 vols. Weimar: Hermann Böhlau, 1887-1919.

-. Sämtliche Werke. Briefe, Tagebücher und Gespräche. Edited by Hendrik Birus, Dieter Borchmeyer, Karl Eibl, et. al. 40 vols. Frankfurt: Deutscher Klassiker Verlag, 1987-2013.

Goethe-Handbuch Supplemente: Band 3: Kunst. Edited by Gabriele Busch-Salmen, Manfred Wenzel, Andreas Beyer, and Ernst Osterkamp. Stuttgart: Verlag J. B. Metzler, 2008-.

Gray, Richard T. About Face: German Physiognomic Thought from Lavater to Auschwitz. Detroit: Wayne State UP, 2004.

Hagen, Waltraud. Die Drucke von Goethes Werken. Berlin: Akademie Verlag, 1971.

Heins, John P. “'Es ist ja kein Geschriebenes': The Parody of Lavater's Physiognomics in Musäus's Physiognomische Reisen." Lessing Yearbook 29 (1997): 107-30.

Houben, H. H. Kleine Blumen, kleine Blätter aus Biedermeier und Vormärz. Dessau: Rauch, 1925.

Köhler, Astrid. Salonkultur im klassischen Weimar: Geselligkeit als Lebensform und literarisches Konzept. Stuttgart: Metzler, 1996.

Kroeber, Timotheus. Die Goethezeit in Silhouetten. Weimar: Gustav Kiepenheuer, 1911.

Weimarer Klassik. Kultur des Sinnlichen. Edited by Sebastian Böhmer, Christiane Holm, Veronika Spinner, and Thorsten Valk. Berlin: Deutscher Kunstverlag, 2012.

Lavater, Johann Caspar. Essai sur la physiognomie: destiné à faire connoître l'homme et à le faire aimer. 4 vols. La Haye: Imprimé chez Jaques Van Karnebeek, 1781-1803.

-. Physiognomische Fragmente zur Beförderung der Menschenkenntniß und Menschenliebe. 4 vols. Leipzig and Winterthur: Bey Weidmanns Erben, und Heinrich Steiner und Compagnie, 1775-78. 
Lyncker, Karl Wilhelm Heinrich, Freiherr von. $A m$ Weimarischen Hofe unter Amalien und Karl August. Erinnerungen von Karl Frhr. von Lyncker. Edited by Marie Scheller. Berlin: E. S. Mittler, 1912.

Lyon, John B. "'The Science of Sciences': Replication and Reproduction in Lavater's Physiognomics." Eighteenth-Century Studies 40, no. 2 (2007): 257-77.

MacLeod, Catriona. "Cutting up the Salon: Adele Schopenhauer's 'Zwergenhochzeit' and Goethe's 'Hochzeitlied.'” Deutsche Vierteljahrsschrift für Literaturwissenschaft und Geistesgeschichte 89, no. 1 (2015): 70-87.

Micir, Melanie, and Aarthi Vadde. "Obliterature: Toward an Amateur Criticism." Modernism/modernity 25, no. 3 (2018): 517-49.

Paul, Jean. Sämtliche Werke. Edited by Norbert Miller. 10 vols. Darmstadt: Wissenschaftliche Buchgesellschaft, 1959-1996.

Pliny the Elder. The Natural History. Edited and translated by John Bostock and H. T. Riley. London: Taylor and Francis, 1855. http://www.perseus.tufts.edu/hopper/ text?doc=Perseus:text:1999.02.0137:book=35:chapter=43\&highlight=butades. Accessed March 27, 2020.
Robson-Scott, W. D. The Younger Goethe and the Visual Arts. Cambridge: Cambridge UP, 1981.

Rosenblum, Robert. "The Origin of Painting: A Problem in the Iconography of Romantic Classicism." The Art Bulletin 39, no. 4 (1957): 279-90

Runge, Philipp Otto. Philipp Otto Runge: Briefe und Schriften. Edited by Peter Betthausen. Munich: C. H. Beck, 1982.

Rutherford, Emma. Silhouette: The Art of the Shadow. New York: Rizzoli, 2009.

Schiller, Friedrich. Sämtliche Werke. Edited by Gerhard Fricke and Herbert G. Göpfert. 5 vols. Munich: Carl Hanser, 1962.

Sharpe, William Chapman. Grasping Shadows: The Dark Side of Literature, Painting, Photography, and Film. New York: Oxford UP, 2017.

Stoichita, Victor I. A Short History of the Shadow. London: Reaktion, 1997.

Vogel, Juliane. "Schnitt und Linie. Etappen einer Liaison." In Öfnungen: Zur Theorie und Geschichte der Zeichnung, edited by Friedrich Teja Bach and Wolfram Pichler, 141-59. Munich: Wilhelm Fink, 2009. 